\title{
Association Between Atherosclerosis and Monocyte/High Density Lipoprotein Ratio in Patients with Familial Mediterranean Fever
}

\author{
Ailevi Akdeniz Ateşi Olan HastalarınMonosit/Yüksek Dansiteli Lipoprotein \\ Oranının Ateroskleroz ile İlişkisi
}

\section{Zuhal BERKDEMIR CALISKAN $\odot$, Ozge TELCI CAKILLI $\odot$, Yusuf YILMAZ $\odot$, Mustafa CALISKAN $\odot$}

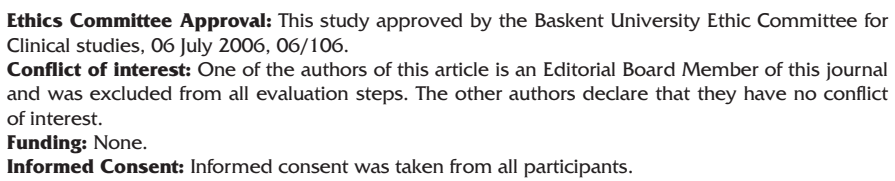

Informed Consent: Informed consent was taken from all participants.

Cite as: Berkdemir Caliskan Z, Telci Caklili O, Yilmaz Y, Caliskan M. Association Between Atherosclerosis and Monocyte/High Density Lipoprotein Ratio in Patients with Familial Mediterranean Fever. Medeniyet Med J. 2019;34:194-9.

Received: 20.02 .2019

\section{ABSTRACT}

Objective: Familial Mediterranean Fever (FMF) is a chronic autosomal recessive disease involving many organs, and tissues mainly peritoneum and pleural tissues and progresses with febrile episodes. In diseases progressing with subclinical inflammation such as FMF along with conventional cardiovascular risk factors oxidative stress, inflammation and endothelial damage can cause cardiovascular diseases. The monocyte/high-density lipoprotein ratio (MHR) may indicate inflammation and oxidative stress due to the proinflammatory effect of the monocytes. We aimed to investigate the relationship between atherosclerosis and monocyte/HDL ratio in patients with FMF.

Method: A total of 40 patients with FMF [21 female, median age: 37 (27-47)] diagnosed with Tel-Hashomer criteria [21 female, median age: 38 (35-40)] who applied to our clinic were included in the study. As a control group age-, and gender-matched 35 healthy volunteer individuals [21 women, median age: 38 (35-40)] were also included in the study and 35 controls. Monocyte/HDL ratio, and coronary flow reserves were evaluated as well.

Results: Demographic characteristics did not differ between both groups. Monocyte count $(0.55 \pm 0.15$ vs. $0.46 \pm 0.14 ; p: 0.013)$ and monocyte $/ H D L$ ratio $(0.014(0.010-0.017)$ vs. 0.010 (0.008-0.013); $p: 0.003$ ) were significantly higher in patients than controls. High sensitive-CRP was also significantly higher in patients with FMF as compared with controls [6.70 (2.7-15.4) vs. $1.75(1.0-2.73), p<0.001]$.

Conclusion: As an easy method to evaluate atherosclerosis monocyte/HDL ratio may gain a role in prediction of coronary microvascular dysfunction in patient with FMF during daily clinical practice.

Keywords: Atherosclerosis, Familial Mediterranean fever, monocyte/high-density lipoprotein ratio, coronary flow velocity reserve

öz

Amaç: Ailevi Akdeniz Ateşi (AAA) başta periton ve plevral dokular olmak üzere birçok doku ve organı etkileyen ataklar halinde giden kronik inflamatuvar otozomal resesif bir hastalıktır. AAA gibi subklinik inflamasyonla giden hastalıklarda klasik kardiovasküler risk faktörlerinin yanı sıra oksidatif stres, inflamasyon ve endotelyal hasar da kardiyovasküler hastalık oluşumuna neden olabilmektedir. Monosit/yüksek dansiteli lipoprotein oranı inflamasyon ve oksidatif stresi monositlerin proenflamatuvar etkileri üzerinden gösterebilmektedir. Bu çalıșmamızda, AAA hastalarında ateroskleroz ve monosit/HDL oranını arasındaki olası bir ilişkiyi araștırdık.

Yöntem: Calışmaya Haziran 2006 ile Ağustos 2018 tarihleri arasında kliniğimize başvurmuş, çaIısmaya dahil edilme kriterlerini tasıyan Tel-Hashomer kriterleri ile tanı konmus 40 AAA hastas [21 kadın, medyan yaş: 37 (27-47)] alındı. Kontrol grubu olarak yaş ve cinsiyet yönünden benzer 35 sağlıklı gönüllü [21 kadın, medyan yaş: 38 (35-40)] alındı. Monosit/HDL oranı yanı sıra koroner akım rezervleri de değerlendirildi.

Bulgular: Gruplar arasında demografik özellikler acısından fark yoktu. Monosit sayısı ve monosit/ $H D L$ oranı hastalarda kontrollerden daha yüksekti $[(0,55 \pm 0,15$ vs $0,46 \pm 0,14 ; p: 0,013)$ ve $(0,014$ $(0,010-0,017)$ vs $0,010(0,008-0,013) ; p: 0,003$, sirasiyla]. Yüksek sensitiviteli C reaktif protein düzeyi de hastalarda daha yüksek olarak bulundu [6,70 (2,7-15,4) vs, 1,75 (1,0-2,73), p<0,001] Sonuç: Monosit/HDL oranı AAA olan hastalarda aterosklerozu erken tanıyabilmek için yeni bir belirteç olabilir ve günlük kullanıma uygundur.

Anahtar kelimeler: Ailevi Akdeniz ateşi, monosit/yüksek dansiteli lipoprotein oranı, ateroskleroz, koroner akım hızı

(c) Copyright Istanbul Medeniyet University Faculty of Medicine. This journal is published by Logos Medical Publishing.

Licenced by Creative Commons Attribution-NonCommercial 4.0 International (CC BY-NC 4.0)
Accepted: 11.03 .2019

Online First: 10.06.2019

Corresponding Author:

O. Telci Caklili

ORCID: 0000-0001-7566-5427 Kocaeli State Hospital, Department of Internal Medicine, Kocaeli - Turkey

wattersonx@gmail.com

Z.B. Calıskan ORCID: 0000-0002-3299-2353 Umraniye Training and Research Hospital, Department of Gastroenterology, Istanbul, Turkey

Y. Yılmaz

ORCID: 0000-0002-6676-2740 Merzifon Karamustafa Pasa State Hospital, Amasya, Turkey

M. Calıșkan ORCID: 0000-0001-7417-4001 Istanbul Medeniyet University, Department of Cardiology, Istanbul, Turkey 
Z. Berkdemir Caliskan et al. Association Between Atherosclerosis and Monocyte/High Density Lipoprotein Ratio in Patients with Familial Mediterranean Fever

\section{INTRODUCTION}

Familial Mediterranean Fever (FMF) is an autosomal recessive disease. It is characterized by serous tissue inflammation caused by increased inflammatory protein levels ${ }^{1}$. It has been reported that subclinical inflammation is still present during attack-free periods in patients with FMF and even among healthy Mediterranean fever gene (MEFV) carriers $^{2-6}$. This continuous inflammation contributes to development of atherosclerosis in these patients. In patients with FMF it has been reported that acute myocardial infarction has occurred due to coronary artery vasculitis without coronary atherosclerosis ${ }^{7}$. In diseases with subclinical inflammation such as FMF along with conventional cardiovascular risk factors such as oxidative stress, inflammation and endothelial damage can cause cardiovascular diseases. A recent study has reported development of coronary microvascular disease in patients with FMF who have not conventional risk factors for cardiovascular disease ${ }^{8}$.

Coronary flow velocity reserve (CFVR) is a noninvasive surrogate marker of coronary microvascular disease (CMD) ${ }^{9}$. Reduced CFVR has been shown to confer prognostic information for cardiovascular outcome in various conditions ${ }^{10}$. Impaired CFVR is also present in systemic inflammation and improves after immunomodulatory treatment ${ }^{11}$.

The monocyte/high-density lipoprotein ratio (MHR) is a newly tested marker to assess proinflammatory effect of the monocytes, combined with anti-inflammatory and antioxidant effect of high-density lipoprotein cholesterol (HDL-C). There are some reports showing association between MHR and atherosclerosis ${ }^{12-18}$. However, MHR has not been tested before to assess a causal relationship with coronary microvascular dysfunction in patients with FMF.

The present study aims to seek for a relationship between coronary microvascular function and monocyte/HDL ratio in patients with FMF.

\section{MATERIAL and METHODS}

This study approved by the Baskent University Ethic Committee for Clinical studies, 06 July 2006, 06/106. Informed consent was taken from all participants.

FMF was diagnosed based on Tel-Hashomer criteria $^{19}$. Patients aged between 18-60 years without cardiovascular risk factors were included. At screening phase ECGs of patients with any symptom related to cardiovascular disease including chest pain were obtained. Stress test was performed in patients with clinical indications and test positive patients were excluded. Other exclusion criteria were; diabetes, hypertension, smoking, patients on vasoactive medication, on corticosteroid and/ or methotrexate and patients with arrythmia except for sinusoidal tachycardia. Patients with body mass indices (BMIs) above $35 \mathrm{~kg} / \mathrm{m}^{2}$ and with serum triglyceride level higher than $\mathrm{mmol} / \mathrm{L}$ (400 $\mathrm{mg} / \mathrm{dL}$ ) were also excluded. At least a 15-day of attack free period was sought before recruiting the patients.

After all inclusion and exclusion criteria were applied 40 patients with FMF [21 female, median age: 37 (27-47) age] and 35 controls [21 females, median age: 38 (35-40)] were recruited from -blinded for peer review. Demographic criteria of the patients were recorded. Sedimentation, high sensitive C-reactive protein (hs-CRP), complete blood count and renal function tests were evaluated. All subjects' blood lipid profile and blood glucose levels were assessed after 12 hours of fasting. Plasma levels of hs-CRP were evaluated with a highly sensitive sandwich ELISA method. Monocyte counts were analyzed with Penta 120 Retic Hematology analyzer (ABX, Montpellier, France). Monocyte/HDL ratio was also calculated.

\section{Imaging techniques}

Echocardiographic evaluations (coronary flow reserve and diastolic function)

Echocardiographic evaluation was performed with a commercially available ultrasound system (S5-1 probe Philips EPIQ /G, Bothell, WA) by an 
experienced cardiologist who was blind to clinical data. Transthoracic Doppler Echocardiography (TTDE) derivate CFVR was performed after intravenous dipyridamole infusion $(0.56 \mathrm{mg} / \mathrm{kg} / 4 \mathrm{~min})^{9}$. Coronary diastolic peak velocities were measured both at baseline and after dipyridamole infusion. CFVR was calculated as the ratio of hyperemic to baseline diastolic peak velocities with CFVR $\geq 2.0$ as normal. The intraobserver-intraclass correlation coefficient for CFVR measurement was 0.946.

Doppler parameters of early $(E)$ and late $(A)$, diastolic transmitral flow velocity, deceleration time of E wave were also measured.

\section{Statistical analysis}

All analyses were performed with SPSS 9.0 (SPSS for Windows 9.0, Chicago, IL). Variables were expressed as mean \pm standard deviation or in parantheses with minimum and maximum values. Normality of distribution of variables was measured by using the Shapiro-Wilk and Kolmogorov-
Smirnov tests. Student t test or Mann-Whitney U test were used for independent group comparisons. A p-value below 0.05 was considered as statistically significant. Pearson and Spearman correlation analysis were used to test the associations between CFVR and disease duration, MHR, biochemical parameters, hs-CRP and echocardiographic parameters.

\section{RESULTS}

\section{Clinical and echocardiographic characteristics of the study population}

The demographic and clinical features of study population are given in Table 1. Both groups were similar regarding age, sex, BMI, systolic and diastolic blood pressure and lipid parameters. Monocyte count $(0.55 \pm 0.15$ vs. $0.46 \pm 0.14$; $p$ value $=$ $0.013)$ and monocyte/HDL ratio $(0.014$ (0.010$0.017)$ vs. $0.010(0.008-0.013)$; $p$ value $=0.003)$ were significantly higher in patients than controls. Hs-CRP was also significantly higher in patients

Table 1. Demographic, laboratory and clinical characteristics of the FMF patients and control groups.

\begin{tabular}{|c|c|c|c|}
\hline & $\begin{array}{l}\text { FMF group } \\
(n=40)\end{array}$ & $\begin{array}{l}\text { Control group } \\
(\mathbf{n}=35)\end{array}$ & P value \\
\hline Age (year), median (IQR) & $37(27-47)$ & $38(35-40)$ & $0.94^{*}$ \\
\hline Male/female (n/n) & $19 / 21$ & $14 / 21$ & $0.52 * *$ \\
\hline Body-mass index $\left(\mathrm{kg} / \mathrm{m}^{2}\right)$ & $25.8 \pm 4.2$ & $26.9 \pm 2.1$ & 0.13 \\
\hline Systolic BP KB (mmHg) & $121.1 \pm 11.7$ & $120.0 \pm 12.4$ & 0.69 \\
\hline Diastolic BP (mmHg) & $77.1 \pm 6.9$ & $76.3 \pm 5.9$ & 0.57 \\
\hline Heart rate (beat/minute) & $73.5 \pm 7.0$ & $72.8 \pm 11.6$ & 0.74 \\
\hline Fasting glucose (mg/dL) & $92.4 \pm 6.2$ & $90.9 \pm 5.4$ & 0.27 \\
\hline BUN (mg/dL) & $19.9 \pm 7.1$ & $18.3 \pm 4.9$ & 0.30 \\
\hline Creatinine (mg/dL) & $0.67 \pm 0.19$ & $0.64 \pm 0.14$ & 0.44 \\
\hline Total cholesterol (mg/dL) & $184.6 \pm 36.9$ & $179.5 \pm 30.7$ & 0.51 \\
\hline \multicolumn{4}{|l|}{ Triglyceride $(\mathrm{mg} / \mathrm{dL}){ }^{*}$} \\
\hline Median (min-max) & $147.5(47.0-259.0)$ & $113.0(42.0-245.0)$ & 0.11 \\
\hline HDL cholesterol (mg/dL) & $42.0 \pm 7.6$ & $44.7 \pm 8.7$ & 0.15 \\
\hline LDL cholesterol (mg/dL) & $113.2 \pm 27.9$ & $110.6 \pm 24.1$ & 0.67 \\
\hline Total WBC count $\left(10^{9} / \mathrm{L}\right)$ & $8.8 \pm 1.9$ & $8.0 \pm 2.1$ & 0.09 \\
\hline Monocyte count $\left(10^{\circ} / \mathrm{L}\right)$ & $0.55 \pm 0.15$ & $0.46 \pm 0.14$ & 0.013 \\
\hline \multicolumn{4}{|l|}{ Monocyte/HDL ratio * } \\
\hline Median (IQR) & $0.014(0.010-0.017)$ & $0.010(0.008-0.013)$ & 0.003 \\
\hline Hemoglobin (mg/dL) & $14.2 \pm 1.4$ & $14.2 \pm 1.1$ & 0.96 \\
\hline \multicolumn{4}{|l|}{$\mathrm{Hs}-\mathrm{CRP}(\mathrm{mg} / \mathrm{dL})$ * } \\
\hline Median (IQR) & $6.70(2.7-15.4)$ & $1.75(1.0-2.7)$ & $<0.001$ \\
\hline $\mathrm{ESR}(\mathrm{mm} / \mathrm{h})$ & $18.2 \pm 13.6$ & - & \\
\hline Disease duration (months) & $65.9 \pm 72.1$ & - & \\
\hline
\end{tabular}

*Mann-Whitney U test, ${ }^{*}$ Chi-square test

Abbreviations: BP: Blood pressure; BUN: blood urea nitrogen; HDL: high-density lipoprotein; IQR: Interquartile range; LDL: lowdensity lipoprotein; WBC: white blood cell; Hs-CRP: high-sensitivity C-reactive protein, ESR: erythrocyte sedimentation rate. 
Z. Berkdemir Caliskan et al. Association Between Atherosclerosis and Monocyte/High Density Lipoprotein Ratio in Patients with Familial Mediterranean Fever

with FMF as compared with controls.

Left ventricular wall thickness (PW and IVS), ventricular diameters, ejection fraction, left atrium diameter and left ventricle mass index (LVMI) were similar between the groups (Table 2). Some of the left ventricular diastolic functions (e.g. mitral $\mathrm{E}$ deceleration time and E/A ratio) were impaired in patient group compared to the control group.

Baseline diastolic peak flow velocity (DPFV) values $(24.1 \pm 3.5$ vs. 22.2 \pm 3.0 ; $p$ value $=0.01)$ were significantly higher in the FMF group. However, hyperemic DPFV values (56.1 \pm 1.0 vs. $68.2 \pm 1.4$; $p$ value $<0.001)$ and CFVR ratio $(2.34 \pm 0.40$ vs. $3.07 \pm 0.48$; $p$ value $<0.001$ were significantly lower in the FMF group. Heart rates at baseline and hyperemia were similar between the groups (Table 2 ).

\section{Correlations between CFVR and other study va- riables}

The Pearson and Spearman's rho correlation analysis showed that in patients with FMF, CFVR was inversely correlated with disease duration
Table 3. Correlations between CFVR and other study variables.

\begin{tabular}{lll}
\hline & R value & P value \\
\hline Disease duration (months) & -0.378 & 0.02 \\
Age (year) & -0.101 & 0.37 \\
Systolic BP (mmHg) & -0.041 & 0.67 \\
Monocyte count (10 $/ \mathrm{L})$ & -0.179 & 0.12 \\
Monocyte count/HDL-C ratio* & -0.262 & 0.02 \\
Fasting glucose (mg/dL) & -0.243 & 0.03 \\
Total cholesterol (mg/dL) & 0.071 & 0.55 \\
LDL-cholesterol (mg/dL) & 0.071 & 0.55 \\
HDL-cholesterol (mg/dL) & 0.353 & 0.002 \\
Hs-CRP (mg/dL)* & -0.535 & $<0.001$ \\
E/A ratio** & 0.302 & 0.009 \\
\hline
\end{tabular}

"Spearman's rho correlation

Abbreviations: BP: Blood pressure; HDL: high-density lipoprotein; LDL: low-density lipoprotein; Hs-CRP: high-sensitivity C-reactive protein; E/A ratio: Mitral E max/Mitral A max

$(\mathrm{r}=-0.378, \mathrm{p}=0.02)$, monocyte/HDL-c ratio ( $\mathrm{r}=-$ 0.262 , $p$ value $=0.02)$, fasting glucose level $(r=-$ 0.243 , $p$ value $=0.03$ ) and hs-CRP $(r=-0.535, p$ value $<0.001)$. Plasma HDL-c levels $(r=0.353, p$ value $=0.002$ ) and $E / A$ ratio (which are representative of LV diastolic function) were positively correlated with CFVR.

Table 2. Comparison of echocardiographic measurements of FMF patients and control groups.

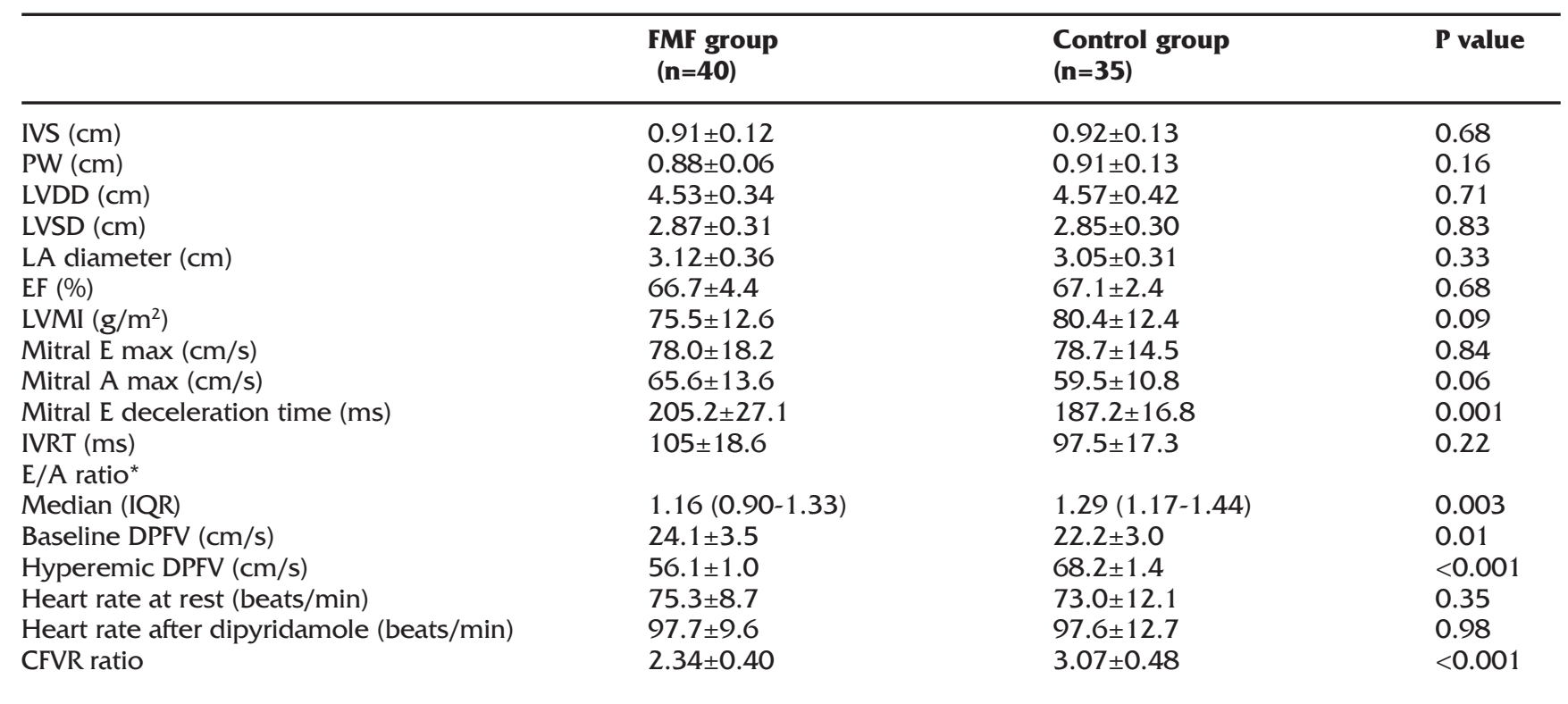

*Mann-Whitney $U$ test

Abbreviations: IVS: interventricular septum; PW: posterior wall; LVDD: left ventricular diastolic diameter; LVSD: left ventricular systolic diameter; LA: Left atrium diameter; EF: ejection fraction; LVMI: left ventricular mass index; E/A ratio: Mitral E max/Mitral A max; IQR: Interquartile range; IVRT: Isovolemic relaxation time DPFV: diastolic peak flow velocity; CFVR: coronary flow velocity reserve. 


\section{DISCUSSION}

Major findings of this study include: (1) in patients with FMF coronary microvascular bed circulation is impaired compared to controls, (2) which is associated with inflammatory markers including hs-CRP and monocyte/HDL ratio and (3) left ventricular dysfunction has also contributed to impairment of CFVR.

Familial Mediterranean fever is a chronic inflammatory disease prevalent in eastern Mediterranean populations including Turkey ${ }^{(1,2)}$. Although there is recurrent chronic inflammation in FMF, any strong evidence for increased atherosclerosis has not been reported. Ugurlu et al. ${ }^{20}$ reported increased carotid artery and femoral artery intima- media thickness in patients with systemic lupus erythematosus. Authors stated statistically significant difference between patients and controls both in carotid intima-media thickness (c-IMT) and atherosclerotic plaques. They also reported increased carotid intima-media thickness and femoral intima- media thickness in patents with FMF however there was no difference regarding presence of atherosclerotic plaques. Akdogan et al. ${ }^{21}$ reported that endothelium-dependent flow- mediated dilatation (FMD) was milder and intima-media of the carotid arteries was thicker in FMF patients compared with healthy controls. Akdogan et al. also reported about the presence of ongoing subclinical inflammation in attack- free periods.

Flow-mediated dilatation (FMD) measured from brachial artery, shows endothelial damage. It is a surrogate marker of early stage atherosclerosis. Both c-IMT and FMD measurements indicate systemic vascular disease. Although systemic vascular disease gives some information about the coronary vascular bed, both peripheral and coronary vascular bed flow patterns dissociate from each other in neurohumoral regulation and many other aspects. Measurement of c-IMT and FMD allows the evaluation of the macrovascular disease. For all these reasons, CFVR measured by TTDE is of great importance both for being a unique diagnostic method for coronary vascular bed and for allowing us to evaluate microvascular di- sease (CFVR $<2$ in patients with open epicardial coronary arteries shows microvascular dysfunction) which represents the earliest stage of atherosclerotic disease. The only study showing that coronary microvascular bed is affected in patients with FMF who don't have classical risk factors for coronary artery disease was reported by Caliskan et al. ${ }^{8}$. Our study is the first study to explain the pathogenesis of deterioration of CFVR in FMF patients. While ongoing inflammation in FMF patients may cause coronary microvascular damage, there may be changes in the functions of protective cholesterols against atherosclerosis, such as HDLcholesterol, without significant changes in lipid levels.

HDL has anti-inflammatory and antioxidant features and there are studies reporting these beneficial features ${ }^{22,23}$. It protects vessel wall by disabling macrophage lipid transportation to the tissue ${ }^{24}$, and inhibits expression of the adhesion molecules through its inhibition of CD $11 \mathrm{~b}$ activation thus attenuating monocyte adhesion to vessel tissue ${ }^{25}$. Along with its anti-inflammatory and antioxidative features, HDL can cause vasorelaxation with its unique ability to increase endothelial nitric oxide synthase expression ${ }^{26-28}$. Thus monocytes have proinflammatory effect, whereas HDL has anti-inflammatory effect opposing inflammatory pathways.

Monocyte/HDL ratio was tested in recent reports: Kanbay et al. ${ }^{29}$ observed an increase in monocyte/ HDL ratio which was associated with reduced glomerular filtration rate; Canpolat et al. ${ }^{30}$ found that high monocyte/HDL ratio was associated with the slow coronary phenomenon. This is the first report to test an association between monocyte/HDL ratio and CFVR in patients with FMF. Findings show that monocyte/HDL ratio was significantly higher in the FMF patients as compared to healthy subjects. Also, monocyte/HDL ratio also has a positive correlation with serum hs-CRP level, which can advocate its role in systemic inflammation. From a clinical point of view, as a novel indicator, monocyte/HDL ratio may have a role in prediction of coronary microvascular dysfunction in patients with FMF during daily clinical practice. 
Z. Berkdemir Caliskan et al. Association Between Atherosclerosis and Monocyte/High Density Lipoprotein Ratio in Patients with Familial Mediterranean Fever

\section{CONCLUSION}

As an easy method to evaluate atherosclerosis monocyte/HDL ratio may gain a role in prediction of coronary microvascular dysfunction in patients with FMF during daily clinical practice.

\section{REFERENCES}

1. Sohar E, Gafni J, Pras M, Heller H. Familial Mediterranean fever a survey of 470 cases and review of the literature. Am J Med. 1967;43:227-53. [CrossRef]

2. Lachmann HJ, Sengul B, Yavuzsen TU et al. Clinical and subclinical inflammation in patients with familial Mediterranean fever and in heterozygous carriers of MEFV mutations. Rheumatology (Oxford). 2006;45:746-50. [CrossRef]

3. Korkmaz C, Ozdogan H, Kasapcopur O, Yazici H. Acute phase response in familial Mediterranean fever. Ann Rheum Dis. 2002;61:79-81. [CrossRef]

4. Musabak U, Sengul A, Oktenli C et al. Does immune activation continue during an attack-free period in familial Mediterranean fever? Clin Exp Immunol. 2004;138:52633. [CrossRef]

5. Ozen S, Bakkaloglu A, Yilmaz E et al. Mutations in the gene for familial Mediterranean fever: do they predispose to inflammation? J Rheumatol. 2003;30:2014-18.

6. Tunca M, Kirkali G, Soytürk M, Akar S, Pepys MB, Hawkins PN. Acute phase response and evolution of familial Mediterranean fever. Lancet. 1999;353:1415. [CrossRef]

7. Serrano R, Martínez MA, Andrés A, Morales JM, Samartin R. Familial mediterranean fever and acute myocardial infarction secondary to coronary vasculitis. Histopathology. 1998;33:163-7. [CrossRef]

8. Caliskan M, Gullu H, Yilmaz S,et al. Impaired coronary microvascular function in familial Mediterranean fever. Atherosclerosis. 2007; 195:161-7. [CrossRef]

9. Gan LM, Wikstrom J, Fritsche-Danielson R. Coronary flow reserve from mouse to man-from mechanistic understanding to future interventions. J Cardiovasc Transl Res. 2013;6:715-28. [CrossRef]

10. Turkmen K, Oflaz $\mathrm{H}$, Uslu B, et al. Coronary flow velocity reserve and carotid intima media thickness in patients with autosomal dominant polycystic kidney disease: from impaired tubules to impaired carotid and coronary arteries. Clin J Am Soc Nephrol. 2008;3:986-91. [CrossRef]

11. van Eijk IC, Peters MJ, Serné EH, et al. Microvascular function is impaired in ankylosing spondylitis and improves after tumour necrosis factor alpha blockade. Ann Rheum Dis. 2009;68:362-6. [CrossRef]

12. Karatas, MB, Çanga Y, Özcan KS, et al. Monocyte to highdensity lipoprotein ratio as a new prognostic marker in patients with STEMI undergoing primary percutaneous coronary intervention. Am J Emerg Med. 2016;34:240-4. [CrossRef]

13. Kundi $\mathrm{H}$, Kiziltunc E, Cetin M, et al. Association of monocyte/HDL-C ratio with SYNTAX scores in patients with stable coronary artery disease. Herz. 2016;41:523-9. [CrossRef]

14. Kanbay M, Solak Y, Unal HU, et al. Monocyte count/ HDL cholesterol ratio and cardiovascular events in patients with chronic kidney disease. Int Urol Nephrol. 2014;46:1619-25. [CrossRef]
15. Canpolat U, Aytemir K, Yorgun H, et al. The role of preprocedural monocyte-to-high-density lipoprotein ratio in prediction of atrial fibrillation recurrence after cryoballoonbased catheter ablation. Europace. 2015;17:1807-15. [CrossRef]

16. Canpolat U, Çetin EH, Cetin S, et al. Association of monocyte-to-HDL cholesterol ratio with slow coronary flow is linked to systemic inflammation. Clin Appl Thromb Hemost. 2016;22:476-82. [CrossRef]

17. Balta S, Celik T, Ozturk C, et al. The relation between monocyte to HDL ratio and no-reflow phenomenonin the patients with acute ST-segment elevation myocardial infarction. Am J Emerg Med. 2016;34:1542-7. [CrossRef]

18. Bolayir A, Gokce SF, Cigdem B, et al. Monocyte/highdensity lipoprotein ratio predicts the mortality in ischemic stroke patients. Neurol Neurochir Pol. 2017;52:150-5. [CrossRef]

19. Samli H, Dogru O, Bukulmez A, Yuksel E, Ovali F, Solak M. Relationship of Tel Hashomer criteria and Mediterranean fever gene mutations in a cohort of Turkish familial Mediterranean fever patients. Saudi Med J. 2006;27:1822-6.

20. Ugurlu S, Seyahi E, Cetinkaya F, Ozbakir F, Balci H, Ozdogan $\mathrm{H}$. Intima-media thickening in patients with familial Mediterranean fever. Rheumatology (Oxford). 2009;48:911-5. [CrossRef]

21. Akdogan A, Calguneri M, Yavuz B, et al. Are familial Mediterranean fever (FMF) patients at increased risk for atherosclerosis? Impaired endothelial function and increased intima media thickness are found in FMF. J Am Coll Cardiol. 2006;48:2351-3. [CrossRef]

22. Barter PJ, Nicholls S, Rye KA, Anantharamaiah GM, Navab $M$, Fogelman AM. Antiinflammatory properties of HDL. Circ Res. 2004;95:764-72. [CrossRef]

23. Cockerill GW, Rye KA, Gamble JR, Vadas MA, Barter PJ. High-density lipoproteins inhibit cytokine-induced expression of endothelial cell adhesion molecules. Arterioscler Thromb Vasc Biol. 1995;15:1987-94. [CrossRef]

24. Zhang Y, Zanotti I, Reilly MP, Glick JM, Rothblat GH, Rader DJ. Overexpression

of apolipoprotein A-I promotes reverse transport of cholesterol from macrophages to feces in vivo. Circulation. 2003;108:661-3. [CrossRef]

25. Murphy AJ, Woollard KJ, Hoang A, et al. High density lipoprotein reduces the human monocyte inflammatory response. Arterioscler Thromb Vasc Biol. 2008;28:2071-7. [CrossRef]

26. Li XP, Zhao SP, Zhang XY, Liu L, Gao M, Zhou QC. Protective effect of high density lipoprotein on endotheliumdependent vasodilatation. Int J Cardiol. 2000;73:231-6. [CrossRef]

27. Kuvin JT, Rämet ME, Patel AR, Pandian NG, Mendelsohn ME, Karas RH. A novel mechanism for the beneficial vascular effects of high-density lipoprotein cholesterol: enhanced vasorelaxation and increased endothelial nitric oxide synthase expression. Am Heart J. 2002;144:16572. [CrossRef]

28. Kuvin JT, Patel AR, Sidhu M, et al. Relation between highdensity lipoprotein cholesterol and peripheral vasomotor function. Am J Cardiol. 2003;92:275-9. [CrossRef]

29. Kanbay M, Solak Y, Unal HU, et al. Monocyte count/ HDL cholesterol ratio and cardiovascular events in patients with chronic kidney disease. Int Urol Nephrol. 2014;46:1619-25. [CrossRef]

30. Canpolat U, Çetin EH, Cetin S, et al. Association of monocyte-to-HDL cholesterol ratio with slow coronary flow is linked to systemic inflammation. Clin Appl Thromb Hemost. 2016;22:476-82. [CrossRef] 